\title{
Nosocomial infection and risk factors in elderly patients in intensive care units
}

\author{
Kevser Özdemir'1, Murat Dizbay² \\ ${ }^{1}$ Denizli State Hospital, Department of Infectious Diseases and Clinical Microbiology, Denizli, Turkey \\ ${ }^{2}$ Gazi University, Faculty of Medicine, Departmentof Infectious Diseases and Clinical Microbiology, Ankara, Turkey
}

\begin{abstract}
Incidence of nosocomial infections gradually increase in patients over 65 years age population. There is a significant relationship between increased age and predisposition to nosocomial infections.

Predisposition to infections in this age group is a result of impaired host defense, underlying chronic diseases, longterm hospitalization, steroids and immunosuppressive therapies and malnutrition. Nevertheless there is not much data about the incidence and risk factors of nosocomial infections in elderly population. In this study we aimed to investigate the incidence and risk factors for nosocomial infections and the factors affecting mortality rates in elderly patients in the medical intensive care units.

Nosocomial infection is an important factor causes increased mortality rate and length of hospital stay. Mortality rates and time interval between admission and discharge is significantly higher in nosocomially infected group than others. There are several known independent risk factors for increased mortality rates include increased age and length of hospital stay, impaired conscious levels, co-morbidities, nosocomial infections, immunsupresive conditions such as malnutrition, malignancies, mechanic ventilation and/or central venous catheter usage.

As a result nosocomial infection is an important and partially preventable risk factor for mortality among patients treated in intensive care units. Mechanical ventilation, central venous and/or urinary catheterizations are such invasive interventions that may cause higher nosocomial infection rates. In terms of decreasing nosocomial infection rates; less frequently used invasive interventions can help in achieving this purpose of treatment. J Microbiol Infect Dis 2015;5(1): 38-43
\end{abstract}

Key words: Nosocomial infection, elderly, intensive care unit, mortality, risk factors

\section{Yoğun bakım ünitelerinde yatan yaşlı hastalarda görülen nozokomiyal infeksiyonlar ve risk faktörleri}

\section{ÖZET}

65 yaş üzerindeki hastalarda nozokomiyal infeksiyon sıkığı her geçen gün artmaktadır ve ilerlemiş hasta yaşı ile nozokomiyal infeksiyon arasında belirgin bir ilişki bulunmaktadır.

Bu hastalarda konak savunmasının azalması, altta yatan kronik hastalıklar, hastanede uzun yatış süresi, malnutrisyon, steroid ve immunsupresif kullanımı infeksiyona zemin hazırlayan diğer faktörlerdir. Maalesef yaşlı hastalarda ortaya çıkan nozokomiyal infeksiyonlar ve risk faktörleri ile ilgili literatürde çok fazla çalışma bulunmamaktadır. Bu çalışmada yoğun bakım ünitelerinde yatan yaşlı hastalarda ortaya çıkan nozokomiyal infeksiyonların risk faktörlerini ve mortalite üzerine olan etkilerini göstermeyi amaçladık.

Nozokomiyal infeksiyonlar hastanede kalış süresini uzatan ve mortaliteyi artıran önemli bir etkendir. Mortalite oranları ve hastaneye yatış ile taburculuk arasında geçen süre nozokomiyal infeksiyonu olan hastalarda belirgin olarak daha fazladır. Yoğun bakım ünitelerinde, ileri yaş, hastanede uzun yatış süresi, altta yatan hastalıklar, nozokomiyal infeksiyonlar, immunsupresif durumlar, uygulanan invaziv girisimler mortaliteyi artıran bağımsız risk faktörleridir.

Sonuc olarak nozokomiyal infeksiyonlar yoğun bakım hastaları icin mortalite üzerinde önemli etkisi olan ve kısmen önlenebilir bir risk faktörüdür. Uygulanan invaziv işlemlerin azaltılması bu infeksiyonlardan korunmada önemli bir rol oynamaktadır.

Anahtar kelimeler: Nozokomiyal infeksiyon, yaşlı, yoğun bakım, mortalite, risk faktörleri

Correspondence: Kevser Ozdemir, Denizli State Hospital, Department of Infectious Diseases and Clinical Microbiology Murat Dede Mah. Şehit Albay Karaoğlanoğlu Cad. No:1, Denizli, Turkey Email: drkevser@gmail.com

Received: 29,June,2014, Accepted: 28,October,2014

Copyright (C) Journal of Microbiology and Infectious Diseases 2015, All rights reserved 


\section{INTRODUCTION}

Worldwide aged population has been increasing. The frequency and severity of infectious diseases also increase in elderly patients because of humoral and cellular immunity changes, organ and tissue dysfunctions and underlying chronic diseases in this patient group. The absolute increase of the elderly population results in increased number of hospitalized elderly patients in the intensive care unit (ICU). Although nosocomial infections occurring in ICU is a major problem, the risk factors for nosocomial infections in the elderly patients have not been sufficiently studied. In this review, the incidence and risk factors for nosocomial infections and the factors affecting mortality rates in elderly patients admitted ICU were presented..$^{1,2}$

\section{Epidemiology of Nosocomial Infections}

Incidence of nosocomial infections in developed countries varies between $5-10 \%$, whereas in developing countries the ratio is reported up to $25 \%$. Nosocomial infections are a major problem in health sector in terms of morbidity and mortality as well as prolonged hospitalization and increased costs. ${ }^{1,2}$ In the United States, it is reported that at least 30,000 people dies due to nosocomial infections per year and patient hospitalization period extends 7-10 days and also 10 billion dollars extra cost per year is spent. The additional mortality rate of nosocomial infections is up to $33 \%$ and the highest mortality rates occur after nosocomial pneumonia. ${ }^{2}$

\section{Types of Nosocomial Infections}

Pneumonia, urinary tract infections (UTI) and bloodstream infections (BSI) are the most common ICUacquired infections. According to EPIC study, the most frequent infections were pneumonia $(46.9 \%)$, other infections of the respiratory tract $(17.8 \%)$, UI $(17.6 \%)$ and $\mathrm{BSI}(12 \%) .^{3}$ Again, according to the NNIS data pneumonia and lower respiratory tract infections, UTI and BSI were the most frequently detected infections. ${ }^{4}$

Invasive device-associated infections were seen often as a ventilator-associated pneumonia (VAP), urinary catheter associated urinary tract infection (UCAUI) or central venous catheter-related bacteremia (CVCRB). Invasive interventions and frequency of invasive interventions are the most important factors in infection's speed. Ventilator-associated pneumonia is the most common infection in adult ICUs and is seen in 10 to $20 \%$ of patients receiving mechanical ventilatory support. ${ }^{5}$
The use of multiple catheters, catheter insertion in emergency conditions, and prolonged use of catheters are the main causes of catheter-related bloodstream infections. Bloodstream infections are most commonly seen in the ICU and its mortality rate is quite high $(25-50 \%)$. Coagulase-negative staphylococci (CNS) are the most frequently isolated pathogens. Staphylococcus aureus, Enterococci and Candida species are the other important pathogens. ${ }^{6}$

Urinary catheters are responsible for $80 \%$ of nosocomial UTI. In a study conducted in Turkey, the percentage of urinary tract infections associated with catheter was reported as $62,4 \%$. The most common factors are, E. coli, Klebsiella pneumoniae, Pseudomonas aeruginosa, enterococci and Candida. ${ }^{6}$ Factors encountered may vary between regions, hospitals, and even within the same hospital and same intensive care unit. In EPIC study, the most frequent factors were enteric gram-negative bacteria $(34.4 \%), S$. aureus $(30.1 \%), P$. aeruginosa (28.7\%), CNS $(19.1 \%)$, yeasts $(17.1 \%)$ and enterococci (\% 11.7). In infections associated with invasive devices, for CVCRB; CNS and Candida spp., for VAP; Acinetobacter spp. and Pseudomonas spp., for UCAUI; Candida spp. factors are the most frequently detected microorganisms. ${ }^{3}$

\section{Emerging Problem in Intensive Care Units: Nosocomial Infections}

Intensive care units are multidisciplinary units and invasive diagnostic and therapeutic interventions are used frequently in this units. ${ }^{7}$ According to the definition by the CDC; ICU Infections are infections that start after 48-72 hours of admission, in patients who is not infected or in incubation period at admission. ${ }^{8}$ Nosocomial infections are the most common complication in patients who are hospitalized in the ICU and incidence of $\mathrm{NI}$ is reported $15-40 \%$ in the ICU. ${ }^{7}$ The European Prevalence of Infection in Intensive Care (EPIC) study, conducted in 1417 patients in 17 Europe countries, reported that $20 \%$ of patients developed infection in the intensive care. Infected patients consist of $5-10 \%$ hospitalized patients however ICU infections constitute $25 \%$ of all nosocomial infections. The incidence of $\mathrm{NI}$ in ICUs is 5-10 times higher than $\mathrm{NI}$ in other wards. ${ }^{9}$ The most important factors in increased infection rates in ICU are; staying in the ICU more than 48 hours, presence of invasive devices such as mechanical ventilation, urinary catheter and central line, prophylaxis of stress ulcer, and trauma. ${ }^{10}$ In addition to these factors, underlying chronic diseases, long-term hos- 
pitalization, immunosuppression secondary to multiple organ failure, steroids and immunosuppressive therapies, number of invasive procedures, intensive antibiotic use, malnutrition and advanced age can be accounted for increased infection rate. ${ }^{3}$

\section{Infectious Diseases in the Elderly}

The World Health Organization (WHO) describes older age as 65 years or older. In the last 30 years, population over 65 years is increased at a ratio of $63 \%$ in the world and this increase is rising constantly. It is estimated that at the year 2025 world's elderly population will exceed 800 million and the females will form the majority of them and about $20 \%$ of the world population will be 65 years and older in 2050. 2,10

Increasing ratio of elderly population results in increased health problems of this age group. This problem is a worldwide community problem. The incidence of infectious diseases that diagnosed in elderly is also increased. The diagnoses and treatments of infectious diseases in elderly require to be familiar to the characteristics of elderly population. ${ }^{11}$ Defining the risk factors, which promote infections, has a key role in management.

\section{Clinical Findings and Risk Factors in Elderly}

Elderly people have a host defense system, which has an impaired ability to fight with infectious agents. Aging of the immune system, chronic diseases, malnutrition and functional deficiencies (immobilization, incontinence, dysphagia) are the factors that affect immunocompromised people. ${ }^{11}$ Infectious diseases in the elderly people were seen more often and seriously than young people. Clinical findings can also be very insidious and different in elderly patients. Deterioration in consciousness, apathy, incontinence, or tachycardia, tachypnea may be the only indication of infection. ${ }^{12}$ Fever, despite being one of the main findings of infection, in elderly patients may not occur every time. Fever in the elderly people may occur more lately and may not rise to high temperatures like in young people. Reduction of fever response in the elderly people is probably due to a disorder in thermal homeostasis. It is concerned that there is a decreased sensitivity to endogenous pyrogen substances in hypothalamus. Malnutrition, circulatory disorders, decrease of fluid intake is the factors that affect fever response. The reasons of increase susceptibility to infectious diseases may be classified as follows; weakening of cellular and humoral immunity, age related changes in tissues and organs and chronic diseases. ${ }^{13}$

\section{Immune System Changes}

Aging is associated with changes in immune system function resulting in increased susceptibility to infection. In the aging process all parts of the immune system are not affected equally. The main change in the immune system is related with cellular immune system. T-cell mediated immunity is reduced. Relationship between humoral and cellular responses is detoriated and humoral immune responses are also negatively affected. In elderly people, polymorphonuclear leukocyte count in peripheral blood is normal and complement system functions are also normal. ${ }^{14-16}$ However, only $50 \%$ of lymphocytes remain with normal function. Another factor in cellular immunity in elderly people is the atrophy of the thymus, which is an important organ in immunity, and the lack of thymic hormones. As a result, the number of $T$ lymphocytes derived from thymus is reduced. This condition is documented with anergic skin test. Changes in the humoral immune system, is caused by $B$ cell response, which is dependent on T cell functions. T cell dysfunction causes changes in antibody response. Although the total amount of antibody remains stable, amount of antibody to foreign antigens are decreased and autoantibodies are increased. ${ }^{14,15}$

\section{Tissue and Organ Changes}

Tissue and organ changes with aging which predispose to infections are as follows: decreased gastric acidity (atrophic gastritis and pernicious anemia) and bowel peristaltism, ciliary dysfunction in respiratory system, disorder of reflexes, loss of lipid and water content in skin, decreased local secretions (lysozyme, iron binding protein, IgG and capacitance), decrease in kidney and liver function, uterine prolapse, bladder diverticula, prostatic hypertrophy. ${ }^{16}$

\section{Underlying Chronic Diseases}

Aging increases the incidence of chronic diseases and facilitates development of infections. Chronic obstructive pulmonary disease (COPD), neurological diseases, diabetes mellitus (DM), solid tumors, rheumatoid arthritis, prostate hypertrophy, atherosclerosis are the disease have been implicated as predisposing factors for infection in the elderly population. ${ }^{16}$ Defective respiratory mucosal defense mechanisms in COPD patients facilitate aspiration and predispose to infections. Neurological disorders such as dementia, stroke, chronic demyelinating disease of the elderly patients predispose to infections due to bedridden, food aspiration and urine and stool incontinence. Solid tumors may 
predispose to infections by blocking the secretory pathway (bronchi, bile, prostate) or by reducing the immune response due to the radiotherapy and chemotherapy. Some diseases such as rheumatoid arthritis, diabetes mellitus, impair leukocyte functions and may lead tendency to infections. ${ }^{13}$

Nosocomial infections, especially in the ICU are major causes of morbidity and mortality, prolonged hospital stay and increased cost. Nosocomial infections are common in ICU units that are 5-10 times higher compared to other clinical incidence of infection. ${ }^{7}$ The underlying disease, the use of broadspectrum antibiotics, the incidence of invasive procedures and longer hospital stay increase infection rates in ICUs. Significant portion of these infections can be prevented with regular surveillance and infection control measures, the implementation of programs. According to results of studies, $\mathrm{NI}$ incidence can be vary among ICU type, patient population, type of invasive interventions and underlying chronic illness. At various centers in Europe and the U.S. the first three $\mathrm{NI}$ are pneumonia, urinary tract infections and bacteremia. EPIC study, have been reported that the most frequent infections were pneumonia $(46.9 \%)$, other infections of airways (17.8\%), UI (17.6\%) and BSI (12\%). ${ }^{3}$

In the U.S. a 5-year surveillance study conducted in the medical ICU. It has been reported that first three $\mathrm{NI}$ were $\mathrm{UI}$, pneumonia and BSI. ${ }^{17}$ Richards et al. ${ }^{18}$ reported that pneumonia ratio was $83 \%$ in patients mechanically ventilated while BSI ratio was $87 \%$ in central venous catheter inserted patients and urinary tract infection ratio was $97 \%$ in patients inserted urinary catheterization. Leblebicioğlu et al. ${ }^{19}$ reported that most common MI was VAP and its followed by BSI and UI respectively.

The most important risk factors of ICU acquired infections in the literature are patients with serious underlying diseases, longer ICU stay, multiorgan failure in patients with immune system suppression, immunosuppressive and steroid therapy implementation, commonly used invasive procedures, increasing of the resistant microorganisms colonization, inadequate and untrained health care personnel. EPIC study determined several risk factors for development of nosocomial infection, which include prolonged hospitalization duration, trauma, ulcer prophylaxis with mechanical ventilation, central venous, pulmonary artery and urinary catheter usage. ${ }^{3}$ The most important risk factors for ICU infections are ICU admissions more than 48 hours, mechanical ventilation, trauma, central venous catheterization and stress ulcer prophylaxis. ICU patients have several risk factors concurrently and increased infection prevalence is closely associated with increased risk factors. ${ }^{10}$ There are many studies, which determine the risk factors for ICU infections however a small number of studies enroll geriatric ICU patients. Another study was determined several risk factors for ICU infections in elderly. These are; more than two invasive catheter insertion, urinary catheter insertion and maintenance, mechanical ventilation, central venous catheter insertion and being a postoperative patient. ${ }^{20}$

There are several studies that show advanced age as a risk factor for nosocomial infection development on the other hand contrary results can be achieved during a literary search..$^{19,21,22,23}$ Leone et al. ${ }^{21}$ conducted an ICU and trauma center study in France and showed close relationship between advanced age, prolonged hospital stay and NI. Rosales et al. ${ }^{22}$ determined the advanced age and prolonged hospital stay as important risk factors for $\mathrm{NI}$ and mortality. The results of this study correlated with EPIC study results. ${ }^{3}$ The discrepancy between studies may result from different ICU status, patient population, severity of disease at admission, invasive interventions and different $\mathrm{NI}$ definitions with standardization.

Ventilator related pneumonia, central venous catheter infections and urinary catheter related infections were commonly seen in ICU patients due to high invasive device usage. In order to determinate ICU infection rates and compare intra and inter hospital infection rates, invasive device related infection (IDRI) rates have to be used. In 2008 ventilator associated pneumonia incidence in elderly was 21.6 per 1000 day with any catheter while 26.4 in adult patients. Urinary catheter related infection incidence was 9.3 versus 10.2 while CVCRB incidence was 2.2 versus 10.1 . There was no significant difference in terms of VAP and UCAUI but CVCRB incidences were significantly differed. One possible explanation of this result may be the higher hematological malignancy rates seen in adult population and the tendency of catheter related infection development in this subgroup of patients. ${ }^{24}$

Ozdemir et al. ${ }^{10}$ showed high infection rates in ICU patients despite low invasive device usage. The authors stated that problems related with invasive device usage and maintenance is responsible for study results. INICC study investigates IDRI rates in ICU in developing countries and results of this study are similar with results achieved in our country. Ozdemir et al. ${ }^{10}$ reported a VAP rate of $\% 19.8$ (9.6-24.1), UCAUI rate of \%6.6 (2.5-8.5) and 
a CVCRI rate of \%8.9 (3.7-16.5) in Gazi University ICU. When compared with INICC study results VAP rate is at $50^{\text {th }}$ percentile, UCAUI rate is at $75^{\text {th }}$ percentile and CVCRI rate is at $25^{\text {th }}$ percentile. ${ }^{25} \mathrm{Ac}$ cording to these results we can say that additional to problems related with adapting infection control cautions, severity of co-morbidities of patients admitting ICU leads increased infection rates.

When we make a literature review, we can see that nosocomial pneumonia is the leading $\mathrm{NI}$ in elderly similar with adult patient population. Impairment of pulmonary and immune functions at elderly along with increased gram-negative bacillary colonization in upper airways is thought to be responsible for this result. However nosocomial pneumonias in ICU are commonly due to ventilator related and there is no significant difference between risk factors of adults and elderly. The most important risk factors for VAP are intubation and mechanical ventilation. Endotracheal intubation damages mucociliary activity and cough reflexes. VAP risk increases and reaches $25-70 \%$ in patients mechanically ventilated. MV is a significant risk factor alone and prolonged MV duration increases VAP rates. ${ }^{26}$ Torres et al. ${ }^{27}$ showed a $1-3 \%$ increase in VAP rate per day for mechanically ventilated patients and infection rate was $66.8 \%$ in patients mechanically ventilated more than 30 days. Leading microorganism seen in VAP is Acinetobacter spp. in both patient populations. INICC study showed enteric gram-negative bacillary, $P$. aeruginosa, S. aureus and Acinetobacter spp. are isolated in VRP patients' specimens $(26 \%$, $26 \%, 22 \%$ and $20 \%$ respectively). Acinetobacter species able to long-term survive on non-vital surfaces in ICU and inadequate adapting of infection control precautions by staff of ICU results in highcontaminated hands and devices. As a result infection spreads among patients. Despite the similar rates of VRP development between elderly and adult population, VRP related mortality rates are significantly higher in elderly population. As a result VRP is the leading infectious disease among $\mathrm{NI}$ and mortality rates are higher in elderly patients. ${ }^{26,27}$

Bloodstream infections have the third place after pneumonias and urinary tract infections in nosocomial infections. ${ }^{28}$ However different infection rates have been reported by different studies conducted in varied sized hospitals and patient population. EPIC study reported fourth place $(\% 12)$ for $B S I$ in nosocomial infections. ${ }^{3}$ Central venous catheters are primary source of nosocomial blood stream infections. In order to decrease CVCRI rates its recommended to decrease central venous catheter insertions and/or duration of catheter usage. ${ }^{4}$ Most common infectious agents are coagulase negative staphylococcus, $S$. aureus enteric gram negative bacillary and Candida spp. during last decade it has been reported that CNS-related with CVCRB rates was increased by $10 \%$ and especially catheter related sepsis cases were mostly related with CNS epidemia in hospitals. ${ }^{29}$

It has been reported that the proportion of UI to overall ICU infections is $7 \% .^{8-23,6}$ Incidence of UI has been varied between 1.7-8.5 per 1000 catheter day. ${ }^{5,30}$ Advanced age alone is not a risk factor however catheter usage is a significant risk factor. $\mathrm{UI}$ in ICU is mostly related with urinary catheter usage, invasive interventions, duration of admission and catheter usage. Female gender, prolonged hospital stay, prior antibiotic treatments, and duration of catheter were found independent risk factors for UI development. Most frequent isolated microorganisms are Enterococcus species (\%24), Candida albicans (\%31), E. coli (\%15) ${ }^{30}$. Leblebicioğlu et al. ${ }^{19}$ showed that UI incidence among 13 ICU facilities was 8.3 per 1000 catheter day and most frequent microorganism was Candida spp., Enterobacteriaceae and Pseudomonas spp. respectively. Overall Candida spp is the most frequent microorganism isolated in UI. This may be explained with prolonged urinary catheter usage, treated with broad-spectrum antibiotic drugs and especially more frequent diabetes mellitus diagnoses in elderly. Mortality rates secondary to UI are lower than VAP and CVCRB related mortality rates. Infection rates were not differed between age groups however mortality rates are significantly higher in elderly group. ${ }^{18}$

Consequently overall mortality rate of infections in ICU patients varies between $10-80 \%$. Nosocomial pneumonia and bacteremia are associated with 2-3 fold increase in mortality rates. Pneumonia, advanced age (>65), malignancy, immunosuppressive therapy and more than 5 days of ICU admission are important risk factors that affect mortality. Additionally infections developed in ICU are independent risk factors for mortality. Girou et al. Investigated infection development in hospital settings and risk factors and they concluded prolonged hospital stay is the most important risk factor in infection development. ${ }^{17}$

\section{CONCLUSION}

Increased NI incidence occurs in ICU patients. NI's in elderly patients lead higher mortality rates than in adult patient population. It is important to know 
changed immunological and physiological status of elderly patients that facilitate this age group of patients to develop infectious diseases. Other important precautions in order to protect infection development are decreasing invasive procedures and avoiding unnecessary interventions in this patient group.

\section{REFERENCES}

1. Uzun O. Hospital Infections Definitions. Doğanay M, Unal $S$ (Ed). Hospital Infections. Ankara: Bilimsel Tıp Yayınevi 2003;35-37.

2. Blot S, Koulenti D, Dimopoulos G, et al. EU-VAP Study Investigators. Prevalence, risk factors, and mortality for ventilatorassociated pneumonia in middle-aged, old, and very old critically ill patients. Crit Care Med. 2014;42:601-609.

3. Vincent JL, Bihari DJ, Suter PM, et al. The prevalence of nosocomial infection in intensive care units in Europe. Results of the European Prevalence of Infection in Intensive Care (EPIC) Study. EPIC International Advisory Committee. JAMA 1995;274:639-644.

4. National Nosocomial Infections Surveillance (NNIS) System Report, data summary from January 1992 through June 2004, issued October 2004. Am J Infect Control 2004;22:470-485.

5. Ylipalosaari P, Ala-Kokko TI, Laurila J, et al. Epidemiology of intensive care unit (ICU)-acquired infections in a 14-month prospective cohort study in a single mixed Scandinavian university hospital ICU. Acta Anaeesthesiol Scand 2006;50:1192-1197.

6. Leblebicioğlu H. Katater ilişkili üriner sistem infeksiyonları. Köksal İ, Çakar N, Arman D (Ed). Yoğun Bakım İnfeksiyonları. Ankara. Bilimsel Tıp Yayınevi 2005;345-356.

7. Palabıyıkoğlu I. Yoğun bakım ünitesi infeksiyonlarında patogenez. Türkiye Klinikleri J Int Med Sci 2006;2:11-22.

8. Horan TC, Andrus M, Dudeck MA. CDC/NHSN surveillance definition of health care-associated infection and criteria for specific types of infections in the acute care setting. Am J Infect Control 2008;36:309-332.

9. Warren DK, Shukla SJ, Olsen MA, et al. Outcome and attributable cost of ventilator-associated pneumonia among intensive care unit patients in a suburban medical center. Crit Care Med 2003;31:1312-1317

10. Ozdemir K, Dizbay M, Dikmen A. Incidence and risk factors of nosocomial infections in elderly patients in intensive care units. Turkish Journal of Geriatrics 2013;16:155-160.

11. Strausbaugh LJ. Emerging health care-associated infections in the geriatric population. Emerg Infect Dis 2001;7:268-271.

12. Htwe TH, Mushtaq A, Robinson SB, et al.: Infection in the elderly. Infect Dis Clin N Am 2007;21:711-743.

13. Liang SY, Mackowiak PA. Infections in the Elderly. Clin Geriatr Med 2007;23:441-456.

14. Rhyn RL, Roche RJ. Infection in the elderly. In: Brilman JC, Quenze RW eds. Infectious Disease in Emergency Medicine. 2nd ed. Philadelphia: Lippincott Raven, 1998;291-316.
15. Sen P, Middleton JR, Perez G, et al. Host defense abnormalities and infections in older persons. Highlights from Infections in Medicine 1996;11:17-22.

16. Ulutan F. Yaşlılıkta infeksiyonu kolaylaştıran Faktörler ve yaşlılıkta Sık Görülen İnfeksiyonların Özellikleri. Klimik Dergisi 2004;17:139-141.

17. Richards MJ, Edwards JR, Culver DH, Gaynes RP. Nosocomial infections in medical intensive care units in the United States. National Nosocomial Infections Surveillance System. Crit Care Med 1999;27:887-892.

18. Richards MJ, Edwards JR, Culver DH, Gaynes RP. Nosocomial Infections in combined medical-surgical intensive care units in the United States. Infect Control Hosp Epidemiol 2000;21:510-515.

19. Leblebicioglu H, Rosenthal VD, Arikan OA, et al. Turkish Branch of INICC. Device-associated hospital-acquired infection rates in Turkish intensive care units. Findings of the International Nosocomial Infection Control Consortium (INICC). J Hosp Infect 2007;65:251-257.

20. Ribas M, Gontijo Filho P. Comparing hospital infections in the elderly versus younger adults: An Experience in a Brazilian University Hospital. Braz J Infect Dis 2003;7:210-215.

21. Leone M, Albanese J, Garnier F, et al. Risk factors of nosocomial catheter associated urinary tract infection in a polyvalent intensive care unit. Int Care Med 2003;29:23-41.

22. Richards MJ, Edwards JR, Culver DH, Gaynes RP. Nosocomial infections in medical intensive care units in the United States. National Nosocomial Infections Surveillance System. Crit Care Med 1999;27:887-892.

23. Meriç M, Wilke A, Çağlayan Ç, Toker K. Intensive care unitacquired infections: incidence, risk factors and associated mortality in a Turkish University hospital. Jpn J Infect Dis 2005;58:297-302.

24. Jarvis WR, Edwards JR, Culver DH, et al. Nosocomial infection rates in adult and pediatric intensive care units in the United States. National Nosocomial Infections Surveillance System. Am J Med 1991;91:185-191.

25. Rosenthal VD. International Nosocomial Infection Control Consortium (INICC) report, data summary for 2002-2007, Am J Infect Control 2008;36:627-637.

26. Toejada AA, Bello DS, Chacon VE. Risk factors for nosocomial pneumonia in critically ill trauma patients. Crit Care Med 2001;29:304-309.

27. Torres A, El Ebiary M, Rano A. Respiratory infectious complications in the intensive care unit. Clin Chest Med 1999;20:287-301.

28. Eggimann P, Pittet D. Overview of catheter-related infections with special emphasis on prevention based on educational programs. Clin Microbiol Infect 2002;8:295-309.

29. O'Grady NP, Alexander M, Dellinger EP, et al. Guidelines for the prevention of intravascular catheter-related infections. MMWR 2002;10:1-29.

30. Laupland KB, Zygun DA, Davies HD, et al. Incidence and risk factors for acquiring nosocomial urinary tract infection in the critically ill. J Crit Care 2002;17:50-57. 